\title{
The removal of pyritic sulphur from coal by Leptospirillum-like bacteria (Short contribution)
}

\section{U. Merrettig, P. Wlotzka, and U. Onken}

Universität Dortmund, FB Chemietechnik, Lehrstuhl für Technische Chemie B, Postfach 505000, D-4600 Dortmund 50, Federal Republic of Germany

In: Appl Microbiol Biotechnol (1989) 31:626-628

The second paragraph in the left column of page 627 should read as follows:

Analytical procedures. Total sulphur was determined by combustion (Schöninger 1961). The sulphate formed was determined by titration with barium chloride and thorin as indicator (Allenspacher 1982). Pyritic sulphur was analysed by determination of pyritic iron. After extraction of the coal sample with hydrochloric acid pyrite was extracted with nitric acid. Pyritic iron in the second extract was determined photometrically with phenanthroline (Deutsche Norm 1983). 